\title{
Hegel and Global Politics: Communitarianism or Cosmopolitanism?
}

\section{Introduction}

In the last ten years or so, largely because of the impact of globalization, students of political theory have turned their attention to problems relating to global justice and cosmopolitan political thought (e.g. Carter, 2001; Cabrera, 2004; Heater, 1996). This paper considers the political thought of Hegel against this background. There has been some discussion of this issue, but not much (Buchwalter, 2007; Buchwalter 2012; Browning, 2011; Hicks, 1999; 2002; 2012). As a number of others have done, I shall structure the discussion by relating Hegel's thought to the cosmopolitanism versus communitarianism debate (Brown, 1992: 14-15; Brown, 2010a, 74; Brown, 2010b, 141-42; Buchwalter, 2012a: 4; 2012b: 218; Heater, 2002: 15; Hicks, 1999: 128; 2012: 40, 45; Jones, 1999: 203; Thompson, 1992: 112).

In $\$ 259$ of the Philosophy of Right Hegel talks about 'the Idea of the state' in triadic terms. He says that the Idea of the State:

[a] 'has immediate actuality and is the individual state as a self-dependent organism - the Constitution or Constitutional Law;

[b] passes over into the relation of one state to other states - International Law; [c] is the universal Idea as a genus and as an absolute power over individual states... (Hegel, 1979: §259, 160).'

In point [a] above Hegel suggests that the state can provisionally be thought of as an isolated, independent or self-dependent entity, and therefore in abstraction from the relationships in which it stands to other states. He associates the characteristic features of an individual state with its constitution and its principles of constitutional law, that is to say with those peculiarities of its history, its customs and its traditions, which are 
associated with its 'ethical life' (Sittlichkeit), or its existence as a particular political community. In his view, the insights gained by this first way of thinking about the state are important, even necessary, if we wish to understand the Idea of the state. Nevertheless, these insights are partial and one-sided. Something equally important, and just as necessary, is left out by this approach. For an individual state is what it is, not only because of the peculiarities of its own history, but also because it stands in a certain relationship to other states in the international arena. Hegel suggests that an adequate understanding of the Idea of the state must take this into account.

This missing element is captured by the second way of thinking about the Idea of the state, associated with point [b] above, which focuses exclusively on the state insofar as it enters into relations with other states, where the conduct of states is regulated by international law. This is an approach which abstracts from the historical specificities and differences between states and which treats all individual states in the same way, as equals. However, Hegel observes that this second approach to understanding the Idea of the state is also partial and one-sided, because it overlooks completely the significance of those particular historical features of an individual state the importance of which is emphasised by adherents of the first approach.

Hegel insists that the relationship between two individual states could not be a purely 'external' one (Hegel, 1979: §259 Zus, 279). 'There must,' he argues, 'be a third thing standing above' two individual states in the international arena which can 'bind them together' (Hegel, 1979: §259 Zus, 279). However, if this is so, then there must also be a third way of thinking about the Idea of the state, which is superior to either of the first two approaches mentioned in $\$ 259$. We should not assume that we have to make an 'either-or' choice between the two approaches identified by points [a] and [b] above. In Hegel's opinion, this third approach to understanding the Idea of 
the state possesses the strengths of each of these first two approaches and the weaknesses of neither.

This third approach, alluded to in point [c] above, involves an attempt to consider the state both in so far as it might be thought of, abstractly, as an isolated, autonomous entity and as it might be thought of in its relations to other states, each of which is considered to be a component element or part of some higher totality or whole. In $\$ 259$ Hegel maintains that the 'third thing' to which this approach refers can be associated with the World-Mind or, in Hegel's own words, the 'mind which gives itself actuality in world-history and is the absolute judge of states' (Hegel, 1979, §259, 160, 279-80; see also §343, 226).

This raises a number of interesting questions. How, exactly, does Hegel conceive of this last entity - this third thing? What language does he employ when attempting to characterize the idea of this overarching totality or whole? What state of affairs is it, in his view, that possesses an 'absolute power over individual states,' and which he associates with the workings of the World-Mind? There are three interesting possibilities here, each of which constitutes a distinct position within the communitarianism versus cosmopolitanism debate and each of which can be associated with a different reading of Hegel. I shall refer to these by the labels 'communitarianism,' 'strong cosmopolitanism' and 'weak cosmopolitanism' respectively. I shall also suggest that, depending on which reading is adopted, there is an intellectual affinity between Hegel's ideas and those of Carl Schmitt, Alexandre Kojève and Jurgen Habermas respectively.

The first of these possibilities, associated with the 'communitarian' reading of Hegel, is that for Hegel the state of affairs which can and should be seen as the product of the World-Mind and of its development in and through world-history is the 
present situation of endemic conflict and war between individual nation-states in the international arena. This, in Hegel's opinion, is what should be associated with the 'end of history.' War is not, therefore, something which in his view ought to be condemned on moral grounds. Nor is it something that could ever be transcended or superseded. This view is often associated with the doctrine known as 'realism' in the theory of international relations. I shall discuss this communitarian reading in Section One, where I connect Hegel's ideas to those of Carl Schmitt.

The second possibility, at the opposite extreme, and associated with the view that Hegel is a 'strong cosmopolitan' thinker, involves the view that the overarching totality or whole which is referred to by Hegel at the end of $\$ 259$ of the Philosophy of Right is a cosmopolis or world-state. According to this reading, Hegel can be associated with the view that world-history is moving ultimately, not towards a situation of conflict and war between states, but rather towards an era in which the sovereign nation-state, the basic unit of understanding for students of international relations in the modern era, prior to the phenomenon of globalization and the rise of global politics, has finally been transcended, and in which there will be no more conflict or war, or even the possibility of war between states. I shall say something about this reading in Section Two, where I connect Hegel's ideas to those of Alexandre Kojève.

The third possibility is that Hegel is best thought of as attempting to steer a via media between the two extremes of communitarianism, on the one hand, and strong cosmopolitanism on the other. I associate this reading with the notion of weak cosmopolitanism and it is my preferred reading of Hegel. There are a number of reasons for thinking that Hegel is best read in this way, which I shall discuss in Section Three, where I connect Hegel's ideas to those of Jurgen Habermas. However, 
provisionally, we can identify just one of these reasons here. It is that, according to Hegel, world-history is moving, not in the direction of a world-state, but rather toward the creation of a new kind of supra-national or transnational political community, at a regional or intermediate level, between that of the individual nation-state and a world-state. When discussing the possibility of the mergence of such an entity in Europe, Hegel suggests that the relations which exist between the states which are members of such a political community will be based on the principles of reciprocity, mutual recognition and peaceful cooperation rather than conflict and war.

\section{Section 1 \\ Hegel and Communitarianism}

A number of commentators have claimed that Hegel's political thought generally is best thought of as a form of communitarianism. For example, this view has been held by Chris Brown. In a survey of international relations theory which he published in 1992, Brown chose Hegel as the classic representative of communitarianism. In Brown's opinion, at that time, Hegel offers 'the most complete account of the world from a communitarian position' (Brown, 1992: 14, 52-81). Similarly, Derek Heater has argued that Hegel is best seen as a communitarian thinker, because he maintains that 'the central role of the community' as 'the provider of ethical political standards should at all costs be preserved' (Heater, 2002: 15; see also Heater, 2002: 53-56). Finally, Janna Thompson has also claimed that Hegel affirms 'the moral primacy of the community' (Thompson, 1992: 112; see also p. 108). According to Thompson, Hegel maintains that the moral life of individuals is 'completely bound up with their participation' in a particular political community (Thompson, 1992: 113) (my emphasis). 
There are of course different types of political community. However, the communitarian reading of Hegel suggests that when talking, in his Philosophy of Right, about the claims that the community is entitled to make on those individuals who are its member citizens what Hegel has specifically in mind is the modern nationstate. This is interesting for two reasons, each of which can be connected to one 'half' of the locution 'nation-state.' The first of these focuses on the 'state' side of things the fact that, for Hegel, the political community in question is the modern state. This is interesting because although this kind of political community is indeed arguably 'modern,' nevertheless the ideas which Hegel employs to defend the claims which it makes on its citizens are in certain respects not modern at all. For as we have seen (like a number of conservative thinkers) Hegel attaches a considerable degree of importance to history, culture, custom and tradition, that is to say, to those features of an individual nation-state which, because they are an inheritance from the past and very much the products of history, are more appropriately described as being 'premodern' or 'traditional.' Indeed, from the standpoint of this communitarian reading, Hegel's approach to both politics and international relations rests entirely on such ethical principles. It rests exclusively on an appeal to the customs and conventions associated with the 'ethical life' of particular political communities. It is, therefore, based on the concept of pure Sittlichkeit, understood in this particular way (Habermas, 1993a: 1-10; Honneth, 1996: 172-73; Fraser, 2001: 23; Fraser, 2003a: 10, 27-28).

The second reason why the association of Hegel with the modern nation-state is interesting has to do with the other component of this idea, that is to say, with the fact that the political community which Hegel has in mind in the Philosophy of Right is a nation-state. By making this conceptual connection, the communitarian reading in effect presents Hegel as a proponent of nationalism. Leonard Krieger, for example, 
claims that for Hegel 'the prime individuality was the nation (Volk)' (Hegel, 1957: 130). On this reading, Hegel maintained that " "the moral individual" which crystallized what was universal in individual men' was the nation, and that freedom 'could only be realized in the nation' (Krieger, 1957: 130, 132). It is the freedom of 'the people within the nation state' (Krieger, 1957: 137; see also Habermas, 1989a: 257; Avineri, 1962; Avineri, 1979 [1972]: 34-6, 45, 69, 79, 228-29; Moland, 2012a: 151-56). On this view, then, the political community which, according to Hegel, can rightly claim the allegiance of its citizens is indeed a 'community,' in the strict sense of the term. As such it possesses a certain unity. However, this unity is of a very peculiar kind. For what unifies the citizens of this state and brings them together as members of the same political community is the fact that together they constitute a Volk or 'people' with a shared language, culture, customs and traditions. They all possess the same political identity, which is at the same time a national identity. The political community that Hegel has in mind is, therefore, one which is unified in the specific sense of being monolithic, homogeneous, without any internal differentiation. Its basis rests on the principle of 'identity' and it attaches no importance at all to the contrasting principle of 'difference.'

So far as global politics is concerned, the communitarian reading of Hegel maintains that the fundamental unit of analysis is again the nation-state. On this view, in one sense at least, there is no such things as 'global politics.' There is only 'international relations.' Moreover, on this reading, which is based largely on what Hegel says in the final paragraphs of Part Three of the Philosophy of Right (Hegel, 1979: $§ 321-60,208-23)$, when discussing international relations Hegel is in effect an advocate of the doctrine traditionally characterized by students of international relations as 'realism.' As such, Hegel is critical of all political idealists, especially 
Immanuel Kant, whose general outlook, especially in relation to the idea if 'perpetual peace,' he considered to be utopian and impractical (Hegel, 1979: §324, 209-10).

On this view, then, Hegel had no time at all for the notion of cosmopolitanism, or for what today we might call 'global justice.' The critical remarks about Kant which Hegel makes in his essay On the Scientific Ways of Treating Natural Law can be cited to illustrate the point. In this essay, rightly or wrongly, Hegel presents Kant as an enthusiast for the idea of a world-state. He refers to the 'shapelessness of cosmopolitanism,' as it can be found in Kant's writings, and to the 'vacuity' of Kant's idea of 'an international state or a world republic' (Hegel, 1975: 132; see also Buchwalter, 2007: 173, fn 38; Hicks, 1999: 99; Hicks, 2012: 24; Jaeger, 2002: 503; Wendt, 2003: 493).

According to Hegel, on this communitarian reading of his views, such strong cosmopolitan ideas are unrealistic because of their association with the belief that conflict or war between individual nation-states is not only ethically desirable but also practically achievable. Indeed, on some accounts, Hegel is thought of as actually celebrating war as something which is healthy or vital for the well-being of any state. For example, in the Philosophy of Right Hegel maintains at one point that 'successful wars have checked domestic unrest and consolidated the power of the state at home' (Hegel, 1979: §324, 210). He maintains that cohesion, peace, order, stability and social solidarity 'at home' are created and sustained by conflict and war abroad. Hence war is 'not to be regarded as an absolute evil' (Hegel, 1979: §324, 209; see also Avineri, 1961; Browning, 2012).

If this first, communitarian reading is accepted then it follows that Hegel did not take seriously the possibility that the onward march of world history might possibly lead to a situation in which the nation-state, together with the politics of modernity, 
might be transcended and a new era in the history of the human race and its political organization inaugurated. He did not accept the possibility that a new type - sic - of solidary political community, might emerge at the supranational level, whether this is associated with the notion of a world-state or with that of some other form of supranational community. Indeed, on this reading, Hegel's views on war are logically incompatible with cosmopolitan ideas of that kind, as is clear from the criticisms which he makes of Kant (Hegel, 1979: §324, 209-10, 295-6; §333, 213-14; see also Arp, 1999; Mertens, 1995; Shelton, 2000).

Advocates of this communitarian reading maintain that for Hegel the most significant feature of the contemporary situation so far as international relations is concerned is precisely the absence of a world-state, that is to say a supra-national political community, operating at the global level, and possessing the sovereign authority to make and the power to enforce laws. Rather, as is well known, Hegel thinks of the contemporary situation in international relations as being akin to a Hobbesian state of nature, namely a condition, not of peace but of war - a condition which exists, in part, precisely because there is no world-state.

Hegel's views, on this first reading, have a striking affinity with those of Carl Schmitt, who follows him (Kervegan, 1992; Norris, 1998; Winfield, 1991). Both Hegel and Schmitt took the view that solidarity, cohesion, unity and social stability at home, the creation of a 'we' or an 'us,' depends on the existence of something which is other. It depends on the existence of an enemy abroad which will unite us against 'them.' In the case of both Hegel and Schmitt, therefore, one reason for being sceptical about the possibility of the emergence of a cosmopolis or world-state, of which all human beings are the member citizens, is the fact that to postulate the 
existence of such a thing is to wrongly presuppose that it is possible for there to be an 'us' without a 'them' - an 'other' who is either potentially or actually an enemy.

Thus, for example, it was Hegel and not Schmitt who first argued that the ideal of 'perpetual peace' which is so 'often advocated as an ideal towards which humanity should strive' by 'liberal minded' cosmopolitan thinkers such as Kant, is not in practice achievable, because 'the state is an individual, and individuality essentially implies negation’ (Hegel, 1979: §324, 209-10, 295-6; §333, 213-14). As such, it is constituted by reference to something which it 'is not.' Hence, 'even if a number of states' were to make peace with one another and 'make themselves into a family,' according to Hegel this group as an individual 'must engender an opposite and create an enemy’ (Hegel, 1979: §324, 295).

Like Hannah Arendt, who with respect to this issue might also be said to be a follower of Hegel rather than Kant (Burns, 2013), Schmitt insists that 'the political entity,' that is to say the individual nation-state, 'presupposes the real existence of an enemy and therefore coexistence with another political entity,' another nation-state which stands against it. Thus, 'as long as' an individual state exists, there will 'always be in the world more than just one state.' Schmitt concludes from this that 'a worldstate which embraces the entire globe and all of humanity cannot exist.' In Schmitt's opinion, as in that of Hegel on this first reading, 'the political world' is necessarily 'a pluriverse and not a universe' (Schmitt, 1996: 53; Arendt, 1973 [1955]: 84; 2005: 93 96; 1981 [1978]: 200).

\section{Section 2 Hegel as a Strong Cosmopolitan Thinker}

There are occasions when Hegel says things which are inconsistent with the view that he is a communitarian and a realist. An alternative reading of $\$ 259$ of the Philosophy of Right, cited earlier, associates Hegel's views on world history with strong 
cosmopolitanism and the idea of a world-state. This second reading stands directly opposed to the first. On this view, Hegel's ideas stand at the far end of the spectrum from communitarianism in the 'cosmopolitanism versus communitarianism' debate.

Evidence in support of this reading can be found in the Philosophy of Right. There, whilst referring to Lessing's Education of the Human Race (1777-80), Hegel identifies his World-Mind specifically with the mind of 'the human race' and states that it is in world history that 'the question of the perfectibility and Education of the Human Race arises' (Hegel, 1979: §343, 216). This remark suggests that in Hegel's view the higher entity to which the Idea of the state must be related if it is to be comprehensively understood is not the World-Mind simpliciter, but the World-Mind understood more specifically as the mind of humanity. Hegel thinks of this as a coherent, unified entity which is perfecting itself, and gaining knowledge of itself, in and through the course of world history, especially of course in and through the history of philosophy.

On this view, it is the achievement of humanity's self-conscious awareness of itself which, for Hegel, constitutes the ultimate purpose of world history. However, Hegel suggests, this is only possible if certain preconditions are met. In particular it is possible only if world history has created a form of social and political organization which is appropriate to it. In short, it is possible only if the historical evolution of the human race and of the state has fully actualized its potential by generating a worldstate. According to this second reading, then, there are occasions when Hegel affirms - if only implicitly - his commitment to at least one of the fundamental principles of cosmopolitan political thought. He embraces the idea that what stands at the "end of history' is a cosmopolis or world-state the individual member citizens of which will include the entire human race. 
Arguing along these lines, Andrew Vincent has claimed that it is 'obvious that the [nation] state is transcended by the true Hegelian method' (Vincent, 1983: 202). According to Vincent, 'there is no logical reason why' the 'restless movement' of the Hegelian dialectic should 'all of a sudden cease' with Hegel's own day, or why it 'should not drive mankind onward to some form of world order or even state' (Vincent, 1983: 202). Similarly, Peter Nicholson has also suggested that Hegel and those British Idealists who followed him can be read as cosmopolitan thinkers who believed that the emergence of a world-state is not only a practical possibility but also an ethically desirable outcome for world history. According to Nicholson, Bernard Bosanquet certainly took this view. However, Nicholson points out, 'it must be remembered' that Bosanquet 'writes as an Hegelian political philosopher' and that his intellectual position 'even in this final development, remains consistently Hegelian' (Nicholson, 1976: 80, 82). Nicholson insists that Bosanquet was being 'perfectly Hegelian in shifting his attention to the world-state,' and that Bosanquet's endorsement of the idea of a world-state is 'entirely compatible with Hegel's approach' (Nicholson, 1976: 82). These remarks raise some interesting issues regarding the interpretation texts about which I shall say more later.

Of particular interest in this connection is the reading of Hegel advanced by Alexandre Kojève, first in his lectures on Hegel's Phenomenology delivered at the Sorbonne in the nineteen thirties and later in his Outline of a Phenomenology of Right, which was published in 1982 (Kojève, 1996 [1947]; Kojève, 2000b; see also Howse \& Frost, 2000). In the earlier Lectures Kojève argues there that for Hegel the 'masterslave opposition' is 'the motive principle of the historical process' (Kojève, 1996 [1947]: 43-44). What Hegel refers to as 'universal history' is 'the history of the interaction between warlike masters and working slaves,' from which it follows that 
human history 'stops at the moment when the difference, the opposition between master and slave disappears' (Ibid.). This situation can be associated with the emergence of what Kojève refers to as 'the universal and homogeneous state' (Ibid.; see also Kojève, 1996 [1947]: 58; Kojève, 2000a: 168; Kojève, 2000b: 366, 471-75, 479).

How, in Hegel's view, as Kojève understands it, are we to characterize this universal and homogeneous state? With respect to this issue Kojève's Lectures are ambiguous. There are times when Kojève attributes to Hegel the view that the universal and homogeneous state is to be associated with the Napoleonic state of his own day (Kojève, 1996 [1947]: 44). On the other hand, however, there are also occasions when Kojève suggests that for Hegel the universal and homogenous state does not yet exist. Its creation is something which will occur in the future. Moreover, this state is not a particular type of nation-state at all. Rather it is, or will be, a worldstate. Thus, for example, Kojève argues that for Hegel 'man is truly human - that is "individual" - only to the extent that he lives and acts as "recognized" citizen of a State.' However, Kojève goes on, Hegel maintains that the state and world history have not yet fully satisfied the 'human desire for recognition.' Indeed, for Hegel 'the desire for recognition can be completely satisfied, only in and by the universal and homogeneous state. For it is only then, when 'by definition' the state 'embraces the whole of the human race, that it will become 'truly universal,' and all of 'the "specificdifferences" of class, race, and so on, are "overcome"” (Kojève, 1996 [1947]: 237).

Kojève adopts much the same view in his later Outline of a Phenomenology of Right. There he states that the universal and homogeneous state will be a 'political union,' or a 'worldwide juridical union,' which 'will encompass the whole of humanity' (Kojève, 2000b: 126, 157-58, 166fn41, 327, 337). As Robert Howse and 
Bryan-Paul Frost have noted, because for Kojève the universal and homogeneous state 'extends to the entire globe,' it follows that its existence necessarily implies 'the end of the (national) state' as a sovereign body (Howse \& Frost, 2000: 6-7). Following both Hegel and Carl Schmitt, Kojève concedes that the universal and homogeneous state could not, therefore, be 'a State properly so called' (Kojève, 2000b: 141fn28). 'No longer having enemies outside' it, Kojève argues that it will 'cease being a State in the proper sense of the word' (Kojève, 2000b: 141fn28, 327).

Kojève suggests, then, that for Hegel what lies at the 'end of history' is the demise of the nation-state and the emergence of a world-state which encompasses the globe in its entirety, and which contains all human beings as its member citizens. Not surprisingly, Kojève also argues in the later Outline that once the universal and homogeneous state has come into existence there will not be, indeed could not possibly be, any conflict or war between nation-states. This state will, he claims, 'no longer have, by definition, either external wars or internal revolutions' (Kojève, 2000b: 126).

\section{Section 3 \\ Hegel as a Weak Cosmopolitan Thinker}

There is a third possible reading of Hegel, which lies somewhere between the two extremes which have been considered so far. On this view, Hegel is neither a communitarian nor a strong cosmopolitan thinker. Rather, he is an advocate of views which are most appropriately associated with the notion of 'weak,' 'rooted,' 'embedded,' or 'situated' cosmopolitanism (Buchwalter, 2012a: 4; 2012b: 218; Burns, 2013a: 183; 2013b: 76).

We have seen that the communitarian reading of Hegel attributes to him the view that the basic unit of analysis in politics and international relations is the nationstate, whereas the reading which connects Hegel with the idea of strong 
cosmopolitanism suggests that, in his view, the onward march of world history is taking humanity in the direction of a world-state. Not surprisingly, perhaps, the reading which maintains that Hegel is best seen as a weak cosmopolitan thinker suggests that what Hegel actually had in mind is something else. On this third view, Hegel's philosophy of history should be associated with the idea of the emergence of a new kind of political community which will be neither a nation state nor a world state.

There are two different versions of this reading. According to the first, what Hegel envisaged is simply a peaceful federation of states, of the kind occasionally envisaged by Kant. Thus, for example, Steven V. Hicks has claimed that Hegel emphasizes the importance of 'reciprocal recognitive relations and interactions between states based on a just system of international law' (Hicks, 2012: 35). According to Hicks, Hegel believed that 'a global community can be forged' through 'a process of mutual recognition' between states (ibid.). Indeed, in Hick's opinion, Hegel maintained that the world is in fact moving 'in the direction of a new era of global cooperation, interconnection and universalism' (Hicks, 1999: 21). Hicks argues that Hegel envisaged a new 'world order' which would 'promote global peace, progress and human solidarity,' and within which increased 'cooperation among the states of the world' would highlight the 'ineffectiveness of war' as a means of ‘solving international disputes' (Ibid; see also Buchwalter, 2012a-b; Frost, 1996; Hicks, 1995, 2002; Jones, 1999; Mertens, 1995; Vincent, 1983).

On this reading, the overarching totality or whole which Hegel associates with the workings of the World-Mind in $§ 259$ of the Philosophy of Right is not the present condition of endemic conflict and war, as the communitarian-realist reading of Hegel maintains. Nor, however, is it a world-state, as the strong cosmopolitan reading 
suggests. Rather, Hegel envisaged a new global political community which will be founded on the principles of reciprocity, mutual trust and peaceful cooperation between sovereign and independent nation-states. This reading does not, therefore, present Hegel as bringing into question the sovereignty of the nation-state in the sphere of international relations. It claims, simply, that there are times when Hegel suggests that in the future relations between states will be peaceful and cooperative rather than warlike and conflictual, as they have been in the past.

However there is also another version of this reading, which goes further than this, according to which Hegel envisaged the emergence of supra-national political institutions which would operate at a regional or intermediate level, somewhere between that of the individual nation-state and that of a world-state. Evidence in support of the claim that Hegel believed that such an entity might be created by the states in Europe is drawn partly from the Philosophy of Right and partly from his Lectures on the Philosophy of World History. For example, in the first of these texts Hegel notes at one point that 'the European peoples' might be thought of as constituting 'a family,' because there is a common principle 'underlying their legal codes, their customs and their civilization’ (Hegel, 1979 [1821]: §339A, 297). Moreover, in the Philosophy of Right Hegel also considers the possibility that 'a number of states' might again make peace with one another, come together and, thereby, 'make themselves into a family.' Although of course, as we saw earlier, he also states there that this 'group as an individual must engender an opposite and create an enemy’ (Hegel, 1979 [1821]: §324, 295).

This last statement rules out the conclusion that Hegel endorsed the idea of a world-state, for the reasons discussed earlier when talking about the similarity between the views of Hegel and those of Carl Schmitt. However, it does not exclude 
the possibility that in Hegel's opinion a number of European states which possess similar cultural values and legal traditions might indeed come together in this way. It does not rule out the inference that Hegel envisaged the emergence of a supra-national political community in Europe at a regional or intermediate level. Indeed, according to some commentators, Hegel's remarks suggest that he thought that such an eventuality might indeed occur (Buchwalter, 2012b: 214; Cobben, 2012; Hicks, 1999: 115, 199, 215; Hicks, 2002; Hicks, 2012: 39; Moland, 2012: 158-62).

There is an interesting passage in Hegel's Lectures on the Philosophy of World History which touches on this issue. In it Hegel maintains that in 'the modern world,' despite 'all the differences between the individual states' of Europe, which he suggests have in the past been 'the cause of wars,' there nevertheless also 'obtains a unity among them.' The 'trend of the states' of Europe today, he argues, is 'towards uniformity' (Hegel, 1988: 761; see also Avineri, 1979 [1972]: 207; Hicks, 2012: 3739). In the same passage Hegel also maintains that this tendency can be associated with a loss of 'autonomy' or 'political independence' (Ibid.). 'Today,' he argues, 'there is not the same absolute chasm between the states of Europe which prevailed' in the ancient world, for example between 'Greece and Persia' (Ibid.).

It may be that all that Hegel is referring to in this passage is the emergence, within Europe, of a peaceful and co-operative federation of the European states. However, Hegel's remarks in this passage about the loss of autonomy and independence (in effect the loss of sovereignty) of the states of Europe indicate that he actually had something else in mind. Shlomo Avineri has claimed that what Hegel is suggesting here is that 'the world' in its entirety, and not only Europe, 'is about to enter an era of cooperation and universalism' (Avineri, 1979 [1972]: 207). In Avineri's view, what Hegel envisages in this passage is the emergence of 'One World, 
united by culture and reason,' in which sovereignty will 'wither away' and wars 'will gradually disappear' (Ibid.). By implication, therefore, Avineri maintains that this passage supports the view that Hegel is a strong cosmopolitan thinker who foresaw the emergence of a world-state at the global level.

On the other hand, however, Hegel's remarks about the growing 'unity' between states and their 'trend toward uniformity' might be thought to have a narrower application. They could be taken as an allusion to the possibility that the states of Northern and Western Europe might come together into some kind of European Union. Steven V. Hicks has claimed that the European Union, as it exists today, 'seems to be a good example of precisely the kind of "trend towards unity," cooperation and universalism that Hegel envisioned' in his Lectures (Hicks, 2012: 39). Similarly, Andrew Buchwalter has claimed that 'Hegel's idea of a global community' has affinities, not with the idea of a world-state, but rather with the more limited 'institutional structure of the European Union,' because in both cases we find 'the idea of divided and limited sovereignty' and 'an account of transnational interconnectivity' which is 'rooted historically and structurally in the interests and self-understanding of member states' (Buchwalter, 2012b: 228). And Lydia L. Moland has argued, on much the same grounds, that Hegel was 'not opposed to transnational regionalism per se,' and that his 'opposition to a world state' did 'not rule out all transnational organizations' (Moland, 2012: 162, 158).

This raises the issue of Hegel's views regarding citizenship and their relevance for those interested in the current debate surrounding the idea of European citizenship, especially Jurgen Habermas. Before turning to consider that issue, I shall say something about the views which Hegel expresses about citizenship more generally in his Philosophy of Right (Hegel, 1979 [1821]). We have seen that, according to the 
communitarian reading referred to earlier, Hegel was a German nationalist. On that view the society which Hegel defends in the Philosophy of Right is a uniform or culturally homogeneous society which is exclusionary rather than inclusionary because it attaches no importance at all to the values of individuality, plurality, diversity and cultural difference. The suggestion made by advocates of this reading is that in Hegel's view only German nationals should be citizens in his 'ideal society.' For Hegel, then, on this view, citizenship is tied to the notion of national identity.

It is undeniable that there is evidence which supports this reading. For example, Hegel does talk in this way about the 'nation' and the 'spirit of a people' in the Introduction to his Lectures on the Philosophy of World History (Hegel, 1984 [1830]: $51-64,76,80-82,96-97,101-05,109,123,145-46)$. However, there is also at least some evidence which supports a different view. For although it is true that, at the very heart of Hegel's political thought in the Philosophy of Right there is a strong commitment to the value of political inclusion or citizenship, nevertheless it is not the case that in this text Hegel considers the grounds for inclusion as a citizen of his preferred political community to be possession a particular national identity. On the contrary he argues there, in the manner of cosmopolitan theorists, that the basis or ground for granting citizenship in that community, and what all citizens possess in common with one another, despite any differences that might exist between them, is the fact that they are all human beings or 'persons.'

For example, Hegel observes in the Philosophy of Right that 'a man' (sic) 'counts as a man in virtue of his manhood alone, not because he is a Jew, Catholic, Protestant, German, Italian, \&c.' and he insists that this is an assertion which 'is of infinite importance’ (Hegel, 1979: §209, Remark, 134). And in his Lectures on the Philosophy of History he argues at one point that '[u]tterly excluding all specialty, 
therefore, man (sic), in and for himself - in his simple quality as man - has infinite value; and this infinite value abolishes, ipso facto, all particularity attaching to birth or country' (Hegel, 1953: 334).

It is by reference to such cosmopolitan ideas that Hegel opposed social and legal discrimination against, and the political exclusion of, the national or religious minorities of his day, especially 'the Jews.' As he puts it, in the Philosophy of Right, 'the fierce outcry' raised against the Jews 'ignores the fact that they are, above all, men; and manhood, so far from being a mere superficial, abstract quality is on the contrary itself the basis of the fact that what civil rights rouse in their possessors is the feeling of oneself as counting in civil society as a person with rights' (Hegel, 1979: $\S 270$, Remark, 169). Indeed, like Hannah Arendt, who arguably follows him in this regard, Hegel goes so far as to refer to the demand for citizenship, understood in this way, as an 'eternal human right' (Hegel, 1979: §209, Remark, 134; see Burns, 2013a). It is true that Hegel rejected the notion of natural or human rights, as it was understood by liberal thinkers from Locke onwards, not least because, like Edmund Burke and Hannah Arendt, he associated this kind of thinking, together with the 'abstract reasoning' which underpins it, with the radical politics of the French Revolution, to which he strongly objected. This is not to say, however, that Hegel completely rejected the idea of natural or human rights, or the associated idea of natural law (Naturrecht), provided it is differently understood. Indeed he finds a place for this idea, suitably interpreted, in his discussion of 'abstract right' in Part One of his Philosophy of Right (Burns, 1995; Burns, 1996).

Taken out of context, the views on citizenship cited above, like those which Hegel makes about moral personality in the Philosophy of Right, read as if they could have been taken from the writings of Kant. Hegel does appear to write at times as if 
he were a Kantian thinker, and to endorse a strong form of cosmopolitanism.

However, it would be wrong to conclude on these grounds that Hegel

straightforwardly endorsed the cosmopolitan political ideals of Kant, together with the notion of substantive natural or human rights which is usually associated with them. For Hegel was extremely critical of that particular form of cosmopolitanism. Such thinking, he says, is 'defective' because it opposes itself to 'the concrete life of the state’ (Hegel, 1979: §209, Remark, 134).

Hegel does not therefore, as Jurgen Habermas sometimes suggests, reject the standpoint of morality (Moralitat) outright in favour of that of ethics (Sittlichkeit). Rather he takes it up and incorporates it into his understanding of a new kind of 'ethical life,' or reconstructed Sittlichkeit, which he considers to be appropriate for societies in the modern world. Seyla Benhabib has claimed, rightly, that Hegel took care to distance himself from "the "abstract cosmopolitanism" and "universalism" of Kantian ethics' (Benhabib, 1992: 47). This is not to say, however, that Hegel rejected universalism outright, or that he was completely opposed to all forms of cosmopolitanism. As Benhabib has also pointed out, although Hegel did sometimes argue 'as if "the moral point of view" and Sittlichkeit were incompatible' with one another, nevertheless a more accurate account of his views is that in the Philosophy of Right he envisages 'a universalistic moral point of view as situated within an ethical community' (Benhabib, 1992: 11).

We have seen that, according to this reading, for Hegel what binds the individual citizens of the political community which he envisages in Part Three of the Philosophy of Right together, and provides the grounds for citizenship, is not a shared national identity, but rather the fact that they all relate to one another, or reciprocally recognize one another, as free and equal human beings, or 'persons,' who ought for 
that very reason, to be allowed to participate fully in the political life of the community, with the same basic rights and duties. Moreover, Hegel maintains that, in order for this to happen, it is necessary that any irrelevant differences that might exist between them, so far as issues such as nationality or religion are concerned, should be set aside for the purposes of law. This idea might be extended and applied to a discussion of the issue of European citizenship, or membership of the new kind of intermediate, supra-national political community, referred to earlier, which Hegel thought might emerge in Europe. The key figure here is Jurgen Habermas (Habermas, 1989a; Habermas, 1996b; Habermas, 1998a; Habermas, 2006a-c; Habermas, 2007a; Habermas, 2009).

For Habermas a major problem for those involved in European politics today is the need, in the current 'post national constellation,' to create a new kind of political identity for European citizens (Habermas, 2001b; see also Habermas, 1996c; Habermas, 1998a; Habermas, 2007a-b). According to Habermas, the hall-mark of this new European identity is that it will bind the citizens of this supra-national political community together without submerging or suppressing the differences which currently exist between them. Habermas suggests that the pluralist societies of Europe today cannot rely on the outmoded assumptions of 'ethno-nationalism' to perform this task. Indeed, aggressive nationalism is the principal obstacle lying in the way of the achievement of this goal. What is required here, Habermas argues, is a new form of 'civic solidarity,' which might also be termed 'cosmopolitan solidarity,' and which will be based on 'the moral universalism of human rights alone' (Habermas, 2001a: 108). Habermas develops these ideas by invoking the notion of 'constitutional patriotism' (Habermas, 1996b: 465-66; Habermas, 1996c: 500-07; Habermas, 1998a: 
118; Habermas, 2001b: 74; Habermas, 2007a: 53; Habermas, 2007b: 78; see also Cronin, 2003; Ingram, 1996; Moland, 2011: fn8202-03; Muller, 2007).

It might be asked what (if anything) in Habermas's view, is the contribution that Hegel's ideas might make to such a political project? If one reads what Habermas has to say about this issue then it is fairly clear that, in his opinion, the answer to this question is 'nothing' at all. The reason for this is that Habermas tends to read Hegel one-sidedly, as a communitarian thinker. Indeed, for Habermas at times, Hegel is the archetypal representative of the communitarian way of thinking about political issues, which is associated with the philosophy of Aristotle, and which is no longer applicable in the 'post-national' or 'post-traditional' world of today.

On these occasions, then, Habermas suggests that Hegel is a traditionalist rather than a modernist and a philosopher of 'the good' rather than a philosopher of 'the right.' Hegel therefore opposes the standpoint of ethics (Sittlichkeit) to that of morality (Moralitat). In Habermas's opinion, Hegel is like Aristotle and contemporary neo-Aristotelian thinkers a relativist or conventionalist who upholds the 'particularist claims' of 'established forms of life' as opposed to the 'universalistic principles' associated with Kant, cosmopolitanism and modernity (Habermas, 1990: 206; Habermas, 1993a: 1-10; Habermas, 1993b: 21; Habermas, 1993c: 117; Habermas, 1996a: 108; Habermas, 1996b: 492; Habermas, 1998: 215-15; Habermas, 2007a: 15154). Indeed, according to Habermas, the notions of 'cosmopolitan solidarity' and 'constitutional patriotism' which he deploys when discussing the issue of European citizenship are to be associated specifically with the philosophy of Kant rather than with that of Hegel (Habermas, 2001a: 108).

Given Habermas's tendency to read Hegel in this way, his conclusion that Hegel's philosophy has little to offer those interested in discussing the possible 
theoretical grounds which might underpin a commitment to the idea of European citizenship is hardly surprising. From that point of view, Hegel and his ideas are evidently a part of the problem and not a part of the solution. However, a more balanced reading of Hegel, of the kind associated with the notion of weak cosmopolitanism above, leads to a different conclusion.

For example, one implication of the reading of Hegel which presents him as a weak cosmopolitan thinker is that the kind of intermediate political community which Hegel envisages emerging at the European level in Part Three of the Philosophy of Right would not be homogeneous and undifferentiated. It would, rather, be plural and diverse. Although it would certainly be a political 'community,' in the strict sense of the term, nevertheless it would also be a community which is internally differentiated. The only thing that the citizens of this community would have in common, in addition to the fact that they happen to be members of the same political community, is the fact that they are all 'essentially' human beings or persons. So far as their other, nonessential or 'accidental' characteristic features are concerned, for example, their race, nationality, religion or gender, Hegel acknowledges that they could be different. In principle, therefore, this community could be far more plural and diverse, and far less homogeneous, than Habermas's communitarian reading of Hegel suggests.

According to the weak cosmopolitan reading of Hegel, then, the fundamental ties which would bind the citizens of that European political community together would be moral rather than ethical. Hegel's approach to the issue of membership of this community is therefore, like that of Habermas himself, one which is not only 'post-conventionalist' and 'post-traditionalist,' but also 'post-nationalist.'

We saw earlier that in the Philosophy of Right Hegel maintains that 'the European peoples' might be thought of as constituting 'a family' which is associated 
with a new form of political organisation (Hegel, 1979 [1821]: §339A, 297). Given this, it might be asked what, in Hegel's view, is the relationship which exists between social or cultural life of this family, on the one hand, and its political organization on the other? Hegel does not address this question explicitly, so any answer to it will inevitably be to some extent speculative. Moreover, with respect to this issue, the remarks which Hegel does make explicitly pull in different directions. In effect, he suggests that there are two different possible answers.

The first of these answers is to say that what makes the peoples of Europe a family is the fact that they have similar cultures, values, customs and traditions. Moreover, it is similarities of this kind which make it possible for this new type of intermediate political community to emerge at the European level. That is why Hegel emphasises the importance of the fact that there is a common principle 'underlying their legal codes, their customs and their civilization' (Hegel, 1979 [1821]: §339A, 297). On this view, the emergence of the new type of political organization under discussion, and its specific character, reflects an underlying and previously existing social or cultural identity, at a non-political or pre-political level.

The second answer to the above question is somewhat different. For Hegel also suggests in the Philosophy of Right that although the European peoples do indeed constitute a family, nevertheless the reason for this is not because they happen to share the same cultural values, customs and traditions. Rather, it is because they have made a decision to 'make themselves into a family' (Hegel, 1979 [1821]: §324, 295 my emphasis. TB). They have made a commitment to create something new which was not there before, namely a new kind of political community, with a new form of political identity, and by implication a new form of citizenship. Moreover, on this second view, the basis for these things has to do, not with the peculiarities of a shared 
European history, customs and traditions, but rather with the fact that the peoples in question have made a commitment to acknowledging, or reciprocally recognizing, their own common humanity, and hence also their moral right to be included as members of such a community. In this respect Hegel's views on citizenship seem to me to prefigure those of both Hannah Arendt and Jurgen Habermas (Burns, 2013a).

So far as Habermas is concerned, if Hegel is read as a weak cosmopolitan thinker, along the lines indicated above, then the ideas which Habermas associates with the notions of cosmopolitan solidarity and constitutional patriotism, and which he considers to be appropriate as an underpinning for European citizenship, are strikingly similar to Hegel's views on citizenship more generally, provided they are properly understood (Buchwalter, 2012b: 214fn9; Hicks, 1999: 213-16; 2012: 23; Moland, 2012: 202-03fn8). These resemblances are surprising, firstly because, as we have seen, Habermas has a reputation for being and considers himself to be a follower of Kant rather than Hegel; and secondly because Habermas is often critical of Hegel on those occasions when he refers to him. Nevertheless, as Lydia L. Moland has pointed out, it is arguable that provided it is read in a certain way, and contrary to Habermas's own assessment, Hegel's political thought does possess 'the internal resources to interpret and address' what Habermas considers to be the most pressing political problem in Europe today, that of European citizenship.

\section{Conclusion}

We have seen that, so far as questions of global politics are concerned, Hegel's political thought can be and has been understood in a number of ways, some of which are very different, indeed diametrically opposed to one another. This raises the issue of whether there are any limits to what might be regarded as a legitimate reading of a text like Hegel's Philosophy of Right. Take, for example, the strong cosmopolitan belief 
that world history is leading in the direction of the emergence of a world-state, and that this is a good thing. This belief is associated with Hegel, or at least with 'Hegelianism' and an 'Hegelian' approach to questions of global politics, by advocates of the second reading discussed above, especially Alexandre Kojève. However, it seems to me that the evidence that Hegel himself did not hold this view is compelling. In fact, if we focus on Hegel's explicitly stated opinions, it is arguable that the opposite is the case. In my view, then, this reading could not be offered as a plausible interpretation of Hegel's own beliefs. Indeed, very few of those commentators who maintain that Hegel is a cosmopolitan thinker of some kind consider him to be one in this strong sense of the term.

Kojève is notorious for saying that he did not care whether his own readings of texts generally, including presumably those of Hegel, are correct or accurate as a 'commentary' (Kojève, 2000b: 135-36n). He claims, rather, that he is more concerned about using ideas for purposes of his own than offering a true account of what any author actually says or means. In his view, then, the issue of the veracity or accuracy of the reading of Hegel's Phenomenology of Spirit which he offers in his Lectures is of secondary importance. Rather, as with all texts, Kojève maintains that this reading 'owes its importance to the importance of the problems which it raises and discusses,' problems which remain relevant today (Kojève, 2000b: 135-36n). Given this admission, it is not too surprising that Michael S. Roth has characterized Kojève's reading of Hegel as an appropriation of Hegel's ideas rather than as a plausible interpretation of them (Roth, 1988: 81-146).

Arguing in a similar vein, Andrew Buchwalter has argued that for a number of commentators who are interested in discussing the relevance of Hegel's ideas for a discussion of the problems of global politics today, the 'task at hand' is not to present 
an authentic account of Hegel's 'own stated views' (Buchwalter, 2012a: 2). Rather it is again a matter of the 'contemporary appropriation' of Hegel's thought (Buchwalter, 2012a: 2). Their aim, Buchwalter observes, ought rather to be to offer 'a reconstructed “Hegelian" account' which can be brought to bear on current political issues. However Buchwalter concedes that, precisely because it is intended to possess contemporary relevance, such an account may well have to be 'at odds' with at least some of Hegel's own stated views (Buchwalter, 2012a: 2; see also Buchwalter, 2012b: 217).

The risk that is run, and the price that may well have to be paid, by political theorists writing today who are seeking to reconstruct Hegel's ideas, or to bring them 'up-to-date' in this way, is that they will lose contact with Hegel's own authentic and original thought. Whether or not this is indeed what happens, in any given case, will be a matter for argument and debate. Moreover, even if it were the case, one might well agree with Kojève and Buchwalter that this is a price worth paying - that Hegelians writing about global politics today should be more concerned about the contemporary relevance of their reading of Hegel than its historical accuracy. I have addressed some of the theoretical issues relating to the interpretation, appropriation and reconstruction of texts generally elsewhere (Burns, 2011a-b; Burns \& Connelly: 10-16). These theoretical issues are of a general nature. However, they do have an obvious application to the reading of those texts in which Hegel discusses what we now call the problems of global politics.

\section{REFERENCES}

Arendt, H. 1973 [1951]. 'Karl Jaspers: Citizen of the World?', in Men in Dark Times. Harmondsworth: Penguin Books, pp. 84-96.

Arendt, H. 1981 [1978]. The Life of the Mind, Vol. 2, Willing. New York: Harcourt. 
Arendt, H. 2005. The Promise of Politics, Jerome Kohn (ed). New York: Schocken Books, pp. 93-96.

Arp, R. 1999. 'Hegel and the Prospect of Perpetual Peace,' Diálogos, 74: 71-100.

Avineri, S. 1962. 'Hegel and Nationalism,' Review of Politics, 24, 4: 461-82.

Avineri, S. 1961. 'The Problem of War in Hegel's Thought,' Journal of the History of Ideas, 22: 463-74.

Brown, C. 2010. Practical Judgement in International Political Theory: Selected Essays. London: Routledge.

Brown, C. 2010a. 'Towards a Neo-Aristotelian Resolution of the CosmopolitanCommunitarian Debate,' in Practical Judgement in International Political Theory, pp. 72-89.

Brown, C. 2010b. 'Hegel and International Ethics,' in Practical Judgement in International Political Theory, pp. 133-43.

Browning, G. K. 2011. 'Hegel, Global Theory and Recognition,' in Global Theory: From Kant to Hardt and Negri (London: Palgrave), pp.

Browning, G. K. 2012. 'Hegel on War, Recognition and Justice,' in A. Buchwalter ed. Hegel and Global Justice, pp. 193-210.

Buchwalter, A. 2007. 'Hegel's Concept of an International "We",' in Philip T. Grier (ed), Identity and Difference: Studies in Hegel's Logic, Philosophy of Spirit and Politics (Albany: SUNY Press), pp. 155-76.

Buchwalter, A. (ed). 2012. Hegel and Global Justice. Dordrecht, Heidelberg, New York \& London: Springer.

Buchwalter, A. (2012a), 'Hegel and Global Justice: An Introduction,' in A. Buchwalter ed. Hegel and Global Justice, pp. 1-20. 
Buchwalter, A. (2012b), 'Hegel, Global Justice and Mutual Recognition,' in A. Buchwalter ed. Hegel and Global Justice, pp. 211-32.

Burns, T. 1995. 'Hegel and Natural Law Theory,' Politics, 15 (1): 27-32.

Burns, T. 1996. Natural Law and Political Ideology in the Philosophy of Hegel Aldershot: Avebury Press.

Burns, T. 2011a. 'Interpreting and Appropriating Texts in the History of Political Thought: Quentin Skinner and Poststructuralism,' Contemporary Political Theory, 10, 3: 313-31.

Burns, T. 2011b. 'Questions of Method,' in Aristotle and Natural Law. London: Continuum, pp. 12-26.

Burns, T. 2013a. “"The Right to Have Rights": Slavery, Freedom and Citizenship in the Thought of Aristotle, Hegel and Arendt,' in Gabriel R. Ricci (ed), Culture and Civilization, Volume V, Cosmopolitanism and the Global Polity. Rutgers University: Transaction Publishers, pp. 181-207.

Burns, T. 2013b. 'Hegel, Cosmopolitanism and Contemporary Recognition Theory,' in T. Burns \& S. Thompson (eds), Global Justice and the Politics of Recognition. London: Palgrave, pp. 64-87.

Burns, T. \& J. Connelly. 2010. 'Introduction: Straussian Voices,' in T. Burns \& J. Connelly (eds), The Legacy of Leo Strauss. Exeter: Imprint Academic, pp.1-26. Cabrera, L. (2004), Political Theory of Global Justice: A Cosmopolitan Case for a World-State (Routledge).

Carter, A. (2001), The Political Theory of Global Citizenship (London: Routledge).

Cobben, P. 2012. 'The Citizen of the European Union From a Hegelian Perspective,' in Buchwalter (ed), Hegel and Global Justice, pp. 177-92. 
Cronin, Ciaran. 2003. 'Democracy and Collective Identity: In Defence of Constitutional Patriotism,' European Journal of Philosophy, 11, 1: 1-28.

Fraser, N. 2001. 'Recognition Without Ethics', in Mike Featherstone and Scott Lash eds., Theory, Culture and Society, 18, 2-3: 21-42. Special issue on Recognition and Difference.

Fraser, Nancy. 2003a. 'Social Justice in the Age of Identity Politics: Redistribution, Recognition and Participation,' in Nancy Fraser and Axel Honneth, Redistribution or Recognition? A Political-Philosophical Exchange, pp. 7-109.

Fraser, Nancy and Axel Honneth. 2003. Redistribution or Recognition? A PoliticalPhilosophical Exchange. London: Verso.

Frost, M. 1996. Ethics in International Relations: A Constitutive Theory. Cambridge: Cambridge University Press.

Habermas, J. 1989. The New Conservatism: Cultural Criticism and the Historians' Debate, Shierry Weber Nicholsen (ed) \& trans. Richard Wolin, intro. Cambridge: Polity Press.

Habermas, J. 1989a. 'Historical Consciousness and Post-Traditional Identity: The Federal Republic's Orientation to the West,' in The New Conservatism, pp. 24968.

Habermas, J. 1990. 'Morality and Ethical Life: Does Hegel's Critique of Kant Apply to Discourse Ethics?' in Moral Consciousness and Communicative Action. Cambridge: Polity Press, pp. 195-216.

Habermas, J. 1993. Justification and Application: Remarks on Discourse Ethics. Cambridge: Polity Press. 
Habermas, J. 1993a. 'On the Pragmatic, the Ethical and the Moral Employments of Practical Reason,' in Justification and Application: Remarks on Discourse Ethics, pp. 1-18.

Habermas, J. 1993b. 'Remarks on Discourse Ethics,' in Justification and Application: Remarks on Discourse Ethics, pp. 19-111.

Habermas, J. 1993c. 'Lawrence Kohlberg and Neo-Aristotelianism,' in Justification and Application: Remarks on Discourse Ethics, pp. 113-32.

Habermas, J. 1996. Between Facts and Norms: Contributions to a Discourse Theory of Law and Democracy, William Rehg trans. Cambridge: Polity Press.

Habermas, Jurgen. 1996a. 'Popular Sovereignty as Procedure,' in Between Facts and Norms: Contributions to a Discourse Theory of Law and Democracy, William Rehg trans. Cambridge: Polity Press, Appendix I, pp. 463-90.

Habermas, J. 1996b. 'Citizenship and National Identity,' in Between Facts and Norms: Contributions to a Discourse Theory of Law and Democracy, Appendix II, pp. 491-516.

Habermas, J. 1998. The Inclusion of the Other: Studies in Political Theory. Ciaran Cronin \& Pablo de Greiff (eds). Cambridge: Polity Press.

Habermas, J. 1998a. 'The European Nation State: On the Past and Future of Sovereignty and Citizenship,' in The Inclusion of the Other: Studies in Political Theory, pp. 105-28.

Habermas, J. 1998b. 'Struggles for Recognition in the Democratic Constitutional State,' in The Inclusion of the Other: Studies in Political Theory, pp. 203-36.

Habermas, J. 2001. The Postnational Constellation: Political Essays

Habermas, J. 2001a. 'The Postnational Constellation and the Future of Democracy,' in The Postnational Constellation: Political Essays, pp. 58-122. 
Habermas, J. 2002. 'The European Nation-State and the Pressures of Globalization,' in P. de Greiff \& C. Cronin (eds), Global Justice and Transnational Politics (Cambridge, Mass.: MIT Press), pp. 217-34.

Habermas, J. 2006. Time of Transitions. Ciaran Cronin \& Max Pensky (eds) \& trans. Cambridge: Polity Press.

Habermas, J. 2006a. 'Does Europe Need a Constitution?', in Time of Transitions, pp. 89-110.

Habermas, J. 2006b. 'From Power Politics to Cosmopolitan Society,' in Time of Transitions, pp. 19-30.

Habermas, J. 2006c. 'Euroscepticism, Market Europe or a Europe of (World) Citizens?', in Time of Transitions, pp. 73-88.

Habermas, J. 2007. The Divided West. C. Cronin (ed) \& trans. Cambridge: Polity Press.

Habermas, J. 2007a. 'Is the Development of a European Identity Necessary, and is it Possible?', in The Divided West, pp. 67-82.

Habermas, J. 2007b. 'Does the Constitutionalization of International Law Still Have a Chance?,' in The Divided West, pp. 115-93.

Habermas. J. (2008). Europe: The Faltering Project. Ciaran Cronin trans. Cambridge: Polity Press.

Heater, D. 2002. World Citizenship: Cosmopolitan Thinking and its Opponents London: Continuum.

Hegel, G. W. F. 1953. The Philosophy of History. J. Sibree, trans. C. J. Friedrich, intro. New York: Dover Publications.

Hegel, G. W. F. 1975. Natural Law: The Scientific Ways of Treating Natural Law, Its Place in Moral Philosophy and its Relation to the Positive Sciences of Law. T. 
M. Knox, trans. H. B. acton, intro. John R. Silber, foreword. Philadelphia: University of Pennsylvania Press.

Hegel, G. W. F. 1979 [1821]. Philosophy of Right. T. M. Knox trans. Oxford: Oxford University Press.

Hegel, G. W. F. 1984 [1830]). Lectures on the Philosophy of World History:

Introduction. H. B. Nisbet, trans. Duncan Forbes, intro. Cambridge: Cambridge University Press.

Hegel, G. W. F. 1988 [1831]. Vorlesungen über die Philosophie der Weltgeschichte.

G. Lasson (ed). Hamburg: Meiner Verlag.

Hicks, S. V. 1999. International Law and the Possibility of a Just World Order: An Essay on Hegel's Universalism. Amsterdam \& Atlanta, GA.: Rodopi.

Hicks, S. V. 1999a. 'Hegel and Cosmopolitanism,' in International Law and the Possibility of a Just World Order: An Essay on Hegel's Universalism, pp. 69114.

Hicks, S. V. 2002. 'Regionalism, Globalism and the Prospects for World Order: A Hegelian Approach,' Interpretation: A Journal of Political Philosophy, 30, 1 (2002), pp. 49-78.

Hicks, S. V. 2012. 'Hegel on Cosmopolitanism, International Relations and the Challenges of Globalization,' in A. Buchwalter ed. Hegel and Global Justice, pp. 21-47.

Honneth, Axel. 1996. The Struggle for Recognition: The Moral Grammar of Social Conflict. Cambridge Mass: MIT Press.

Howse, R. and B-P. Frost. 2000. 'Introductory Essay: The Plausibility of the Universal and Homogeneous State,' in Kojève, Outline of a Phenomenology of Right, pp. 1-27. 
Ingram. Attracta. 1996. 'Constitutional Patriotism,' Philosophy \& Social Criticism, 22, 6, pp. 1-18.

Jones, C. 2001. 'Neo-Hegelianism, Sovereignty and Rights,' in Global Justice: Defending Cosmopolitanism. Oxford: Oxford University Press, pp. 203-26.

Kervegan, J-F. 1992. Hegel, Carl Schmitt: Le Politique Entre Speculation et Positivite. Paris: Presses Universitaires de France.

Kojève, A. 1996 [1947]. Introduction to the Reading of Hegel: Lectures on the Phenomenology of Spirit, assembled by Raymond Queneau, Alan Bloom (ed), James H. Nichols jnr. trans. Ithaca \& London: Cornell University Press.

Kojève, A. 2000a [1961]. 'Tyranny and Wisdom,' in L. Strauss, On Tyranny: Including the Strauss-Kojève Correspondence, revised and expanded edition, Victor Gourevitch and Michael Roth (eds). Chicago: University of Chicago Press, pp. 135-76.

Kojève, A. 2000b. Outline of a Phenomenology of Right, Robert Howse (ed), BrianPaul Frost \& Robert Howse, trans. Lanham. Md.: Rowman \& Littlefield. Mertens, T. 1995. 'Hegel's Homage to Kant's Perpetual Peace: An Analysis of Hegel’s Philosophy of Right, §§321-40,' The Review of Politics, 57 (4): 66591.

Moland, Lydia L. 2011. Hegel on Political Identity: Patriotism, Nationality, Cosmopolitanism. Evanston, Illinois: Northwestern University Press.

Mullender, R. 2003. 'Hegel, Human Rights and Particularism,' Journal of Law and Society, 30 (4): 554-74.

Muller, Jan-Werner. 2007. Constitutional Patriotism. Princeton, NJ.: Princeton University Press. 
Norris, A. 1998. 'Carl Schmitt on Friends, Enemies and the Political,' Telos, 112: 6889.

Roth, Michael S. (1988), Knowing and History: Appropriations of Hegel in Twentieth Century France (Ithaca: Cornell University Press).

Schmitt, C. 1996 [1927]. The Concept of the Political: With Leo Strauss's Notes on Schmitt's Essay, Intro. George Schwab, Trans. George Schwab and J. Harvey Lomax, Foreword Tracy B. Strong. Chicago: University of Chicago Press.

Shelton, M. 2000. 'The Morality of Peace: Kant and Hegel on the Grounds for Ethical Ideals,' Review of Metaphysics, 54: 379-408.

Thompson, J. 1992. Justice and World Order: A Philosophical Inquiry. London: Routledge.

Vincent, A. 1983. 'The Hegelian State and International Politics,' Review of International Studies, 9: 193-205.

Wendt, A. 2003. 'Why a World State is Inevitable,' European Journal of International Relations, 9 (4): 491-542.

Winfield, R. D. 1991. 'Rethinking Politics: Carl Schmitt Vs Hegel,' Owl of Minerva, 22: 209-17. 